\title{
Serum Zn Content in Tumor-Bearing Rats Treated with Anticancer Drugs
}

\author{
Tatuo Saito, Akira Wakui, Tatsumi Himori, Shigeki Ujile, \\ Nobuo Sugawara and Zensuke Sugryama \\ Department of Clinical Cancer Chemotherapy, The Research \\ Institute for Tuberculosis and Cancer, Tohoku University, \\ Sendai 980
}

Sarto, T., Wakui, A., Hrmori, T., Ujine, S., Sugawara, N. and Sugiyama, Z. Serum $Z n$ Content in Tumor-Bearing Rats Treated with Anticancer Drugs. Tohoku J. exp. Med., $129(2), 111-121$ — The serum $Z n$ content in rats bearing Yoshida-Sarcoma, AH 66F, AH 13 or AH 109A was found to be low as compared with that in normal controls. In the rats which had received intraperitoneal inoculum of Yoshida-Sarcoma, the effects of anticancer drugs were elosely related to the changes in serum $\mathrm{Zn}$ content. Namely, serum $\mathrm{Zn}$ content increased and approached the normal range almost in parallel with the prolongation of survival time by anticancer drugs. As the causes responsible for the reduction in quantity of serum $\mathrm{Zn}$ in the tumor-bearing rats, the reduction of serum albumin content and the accumulation of $\mathrm{Zn}$ in the tumor tissue and organs such as the liver and kidneys were suggested. - serum $\mathrm{Zn}$ content; $\mathrm{Zn}$ content of the organs; influence of anticancer drugs on serum $\mathrm{Zn}$

$\mathrm{Zn}$ is known to be essential for the function of $\mathrm{Zn}$ metalloenzymes. A role of $\mathrm{Zn}$ in polymeric organization of DNA and RNA molecules has been postulated also (Mills et al. 1969; Prasad et al. 1971). Zn stimulates the growth of cells through its effect exerted primarily on RNA synthesis (Wegner and Romano 1963). The DNA synthesis for the regeneration of the rat liver after hepatectomy is markedly or completely inhibited by EDTA. However, $\mathrm{Zn}$ alone among many cations reverses the inhibition of DNA synthesis caused by the chelating agents (Fujioka and Lieberman 1964).

It has been observed that experimental $\mathrm{Zn}$ deficiency led rapidly to the retardation of the growth rate of carcases, and also to the inhibition specifically of the growth of tumors (Dewys et al. 1970; McQuitty et al. 1970; Dewys and Pories 1972). These findings may suggest that $\mathrm{Zn}$ is essential for the normal proliferative processes of the animal cells, and also for the growth of the tumor cells.

Several previous publications showed that serum $\mathrm{Zn}$ content in the hosts

Received for publication, September 19, 1978.

This paper is presented in commemoration of the retirement of Professor Tatuo Saito, the Director of the Research Institute for Tuberculosis and Cancer, Tohoku University, April 1978.

This work was supported in part by a Grant-in-Aid for Cancer Research from the Ministry of Education, Science and Culture, and from the Ministry of Health and Welfare. 
bearing tumor was usually below the normal levels (Devies et al. 1968; Shiraishi et al. 1969; Morgan 1970; Ujiie 1971; Saito et al. 1974).

The present study was designed to investigate the factors which determine the serum $\mathrm{Zn}$ content, and the relationship between the effects of anticancer drugs and the changes in serum $\mathrm{Zn}$ content of the rats bearing tumor.

\section{Materials and Methods}

Animals. Male Donryu rats weighing 100 to $500 \mathrm{~g}$ were used in this study. They were maintained throughout the course of experiment on a solid diet (MF, Oriental Yeast Ind. Co., Tokyo). Tap water was given ad libitum.

Tumor source and the route of inoculation. Ascites hepatoma 13 cells (AH 13), ascites hepatoma 66F cells (AH 66F), ascites hepatoma 109A cells (AH 109A) and YoshidaSarcoma cells (YS), (kindly supplied by Professor Sato, Director of the Cancer Research Laboratory of this Institute) had been maintained in the rats by serial intraperitoneal transplantations, and were used in this study.

The above tumor cells $\left(2 \times 10^{6}\right)$ were suspended in $0.2 \mathrm{ml}$ of sterile physiologic saline and were inoculated into the recipient rats by intraperitoneal or subentaneous route. The animals were divided into the groups of 5 rats in each experiment. Ten untreated rats served as controls.

Anticancer drugs. Anticancer drugs employed in this study and the individual doses were as follows: Ifosfamide (Z-4942) $30 \mathrm{mg} / \mathrm{kg}$, cyclophosphamide (CPM) $10 \mathrm{mg} / \mathrm{kg}$, mitomycin C (MMC) $300 \mu \mathrm{g} / \mathrm{kg}$, carboquone (CQ) $150 \mu \mathrm{g} / \mathrm{kg}$, chromomycin $\mathrm{A}_{3}$ (CHRM) $50 \mu \mathrm{g} / \mathrm{kg}$, actinomycin D (Act-D) $50 \mu \mathrm{g} / \mathrm{kg}$, adriamycin (ADM) $2 \mathrm{mg} / \mathrm{kg}$, 5-fluorouracil (5-FU) $30 \mathrm{mg} / \mathrm{kg}$, furanidyl-5-fluorouracil (FT-207) $300 \mathrm{mg} / \mathrm{kg}, 6$-mercaptopurine (6-MP) $20 \mathrm{mg} / \mathrm{kg}$, and prednisolone $(\mathrm{Ps}) 5 \mathrm{mg} / \mathrm{kg}$.

These agents were given to the normal and the YS-bearing rats intraperitoneally in a single dose at $72 \mathrm{hr}$ after inoculation.

Period of starvation. Ten normal rats weighing 150 to $179 \mathrm{~g}$ were used for this experiment. Five rats were housed in one cage and were maintained on a solid diet for 5 days. Then, the rats were kept unfed for 5 days, only tap water being given freely. Then, they were sacrificed for the measurement of serum $\mathrm{Zn}$ content.

Exsanguination. In the groups of the rats bearing tumor, blood was withdrawn daily from the abdominal artery with a disposable syringe under anesthesia with pentobarbital sodium starting from $24 \mathrm{hr}$ after inoculation. The rats bearing XS and treated with various anticancer drugs were bled at 2 -day intervals from the 2 nd day after administration of the drugs as described above. The control and unfed rats were also bled to death in a similar manner.

Determination of serum $Z n$ content. In order to measure the $\mathrm{Zn}$ content in serum, the serum was diluted with deionized water by a factor of 5 , then the $\mathrm{Zn}$ content was measured with an atomic absorption spectro-photometer (Type 207, Hitachi Ind. Co., Tokyo).

All the glasswares employed for the estimation of $\mathrm{Zn}$ content were first soaked in a cleansing solution consisting of sulphuric acid and potassium dichromate and then in a $20 \%$ solution of nitric acid for $24 \mathrm{hr}$ respectively, subsequently they were washed with several changes of deionized water.

Determination of tissue $\mathrm{Zn}$ content. The normal tissues of the normal or tumorbearing rats and the tumor tissues were completely dried in a desiccator. Then about $1 \mathrm{~g}$ of each tissue was boiled gently for 30 min with $25 \mathrm{ml}$ of a $60 \%$ nitric acid in Kjeldahl's incinerating flasks. After cooling, $15 \mathrm{ml}$ of a $60 \%$ solution of perchloric acid was added and the resulting mixture was heated until the digest became transparent. The samples after 
dilution were used for the determination of $\mathrm{Zn}$ content by the methods as described.

Serum protein analysis. Total serum protein content was measured by a hand protein refractometer (Hitachi Ind. Co., Tokyo). For the fractionation of serum protein, all the sera were electrophoresed for $60-70 \mathrm{~min}$ on a cellulose acetate membrane in a barbital. barbituric acid buffer at $\mathrm{pH} 8.6$ at a constant current of $0.8 \mathrm{~mA} / \mathrm{cm}$. The serum samples $(0.004 \mathrm{ml} / 1.5 \mathrm{~cm})$ were applied on the midline of a $2.4 \mathrm{~cm}$-wide oxoid strip (Oxoid, Ltd., London) with a micropipette. After electrophoretic separation, the strip was stained with Ponceau 3R Extra Pure (Tokushu Chemical Co., Ltd., Tokyo). The air-dried strips were made permeable to light with decahydronaphthalene and then were scanned with a YamatoAsuka model UV 51 densitometer (Yamato-Asuka Ind. Co., Ltd., Tokyo) equipped with interference filters at $500 \mathrm{~nm}$ (motor speed $20 \mathrm{~mm} / \mathrm{min}$, slit $0.2 \times 4 \mathrm{~mm}$ ).

\section{Results}

Serum $Z n$ content of control rats. The mean serum $\mathrm{Zn}$ content of 40 normal male rats was $1.057 \mathrm{ppm}$ with a standard deviation of 0.150 . As shown in Fig. 1, there was no correlation between the serum $\mathrm{Zn}$ content and body weight.

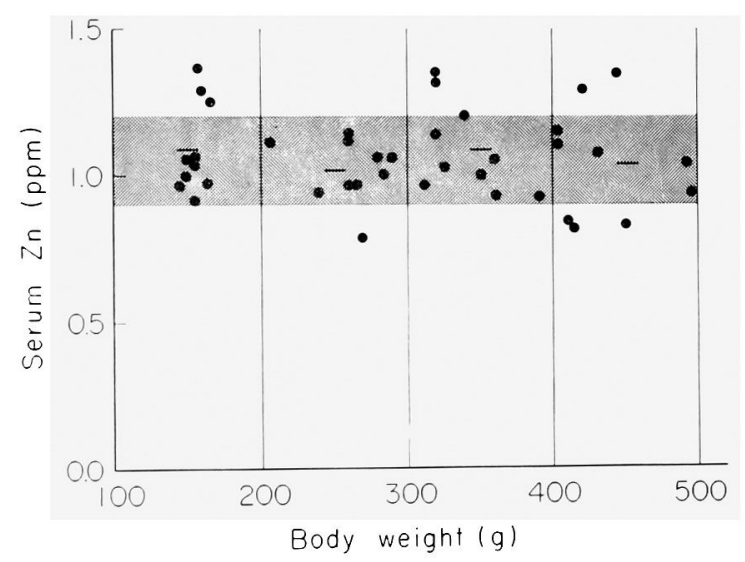

Fig. 1. Serum $\mathrm{Zn}$ content in relation to body weight in normal rats. Shaded area indicates normal range.

Serum $Z n$ and serum protein contents in the rats which were kept unfed. The $\mathrm{Zn}$ content, total protein content and the protein fraction in serum of 5 normal rats which were starved for 5 days with exception of tap water are listed in Table 1. The serum $\mathrm{Zn}$ and total protein contents were within the normal range, when determined 5 days after the animals had been starved. The effect of starvation on serum protein fractions was not found either.

Effect of tumor inoculation on serum $Z$ n content. The fluctuation of serum $\mathrm{Zn}$ content during the course of tumor growth in 4 groups of rats bearing different types of tumor are shown in Fig. 2. There was a tendency for serum Zn content to show similar changes during tumor growth among the above 4 groups. In the early stage, on the 2nd to 3rd day after inoculation, the serum Zn content increased slightly. Thereafter, they began to decrease gradually and were reduced remarkably 
TABLE 1. Serum $Z n$ content, total protein content and serum protein fractions in rats starved for 5 days and in normal rats

\begin{tabular}{|c|c|c|c|c|c|c|}
\hline \multirow{2}{*}{ Rat No. } & \multirow{2}{*}{$\begin{array}{l}\text { Serum zinc } \\
\text { content } \\
\text { (PPM) }\end{array}$} & \multirow{2}{*}{$\begin{array}{l}\text { Serum total } \\
\text { protein } \\
(\mathrm{g} / 100 \mathrm{ml})\end{array}$} & \multicolumn{4}{|c|}{ Serum protein fraction $(\mathrm{g} / 100 \mathrm{ml})$} \\
\hline & & & $\mathrm{Al}$ & $\alpha-\mathrm{G}$ & $\beta-G$ & $\gamma-\mathrm{G}$ \\
\hline \multicolumn{3}{|c|}{ Starved for 5 days } & $(\%)$ & $(\%)$ & $(\%)$ & $(\%)$ \\
\hline 1 & 1.110 & 5.7 & 2. $60(46)$ & $1.54(27)$ & $0.91(16)$ & $0.63(11)$ \\
\hline 2 & 1.040 & 6.4 & $3.20(50)$ & $1.47(23)$ & $0.83(13)$ & $0.90(14)$ \\
\hline 3 & 1. 095 & 6.1 & $3.17(52)$ & 1. $28(21)$ & $0.85(14)$ & $0.79(13)$ \\
\hline 4 & 1.110 & 6.2 & $2.85(46)$ & 1. $49(24)$ & $1.05(17)$ & $0.74(12)$ \\
\hline 5 & 1. 020 & 5.8 & $2.73(47)$ & $1.45(25)$ & $0.87(15)$ & $0.75(13)$ \\
\hline Mean & 1.075 & 6.04 & $2.91(48.2)$ & $1.45(24.0)$ & $0.91(15.0)$ & $0.76(12.6)$ \\
\hline \multicolumn{7}{|l|}{ Normal } \\
\hline 1 & 0.890 & 3.8 & $1.36(43)$ & 1. $37(36)$ & $0.49(13)$ & $0.30(8)$ \\
\hline 2 & 1.285 & 5.6 & $2.35(42)$ & $1.51(27)$ & $0.89(16)$ & $0.78(14)$ \\
\hline 3 & 0.860 & 5.7 & $2.51(44)$ & $1.77(31)$ & $0.86(15)$ & $0.57(10)$ \\
\hline 4 & 1.155 & 6.1 & $2.38(39)$ & $1.71(28)$ & $1.04(17)$ & $0.98(16)$ \\
\hline 5 & 1.210 & 5.4 & $2.43(45)$ & $1.46(27)$ & $0.86(16)$ & $0.65(12)$ \\
\hline Mean & 1. 080 & 5. 32 & $2.26(42.6)$ & $1.56(29.8)$ & $0.83(15.4)$ & $0.66(12.0)$ \\
\hline
\end{tabular}

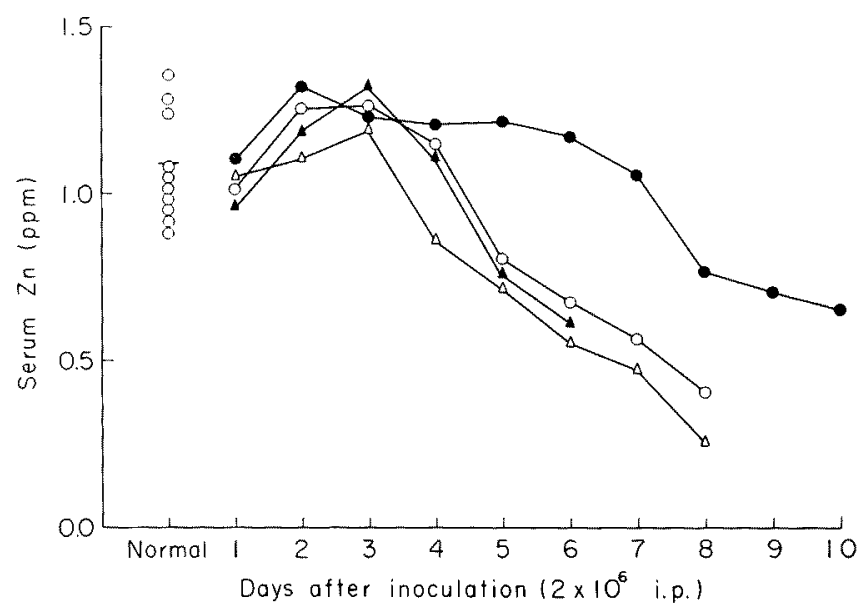

Fig. 2. Fluctuations of serum $\mathrm{Zn}$ content in rats which received intraperitoneal inoculum of AH 109A $\bullet-\bullet)$, YS $(0-0)$, AH $66 \mathrm{~F}(\Delta-\Delta)$, or AH $13(\Delta-\Delta)$.

in the terminal stage. A marked reduction of serum $\mathrm{Zn}$ content was observed at the terminal stage in the rats bearing $\mathrm{YS}$ and $\mathrm{AH} 66 \mathrm{~F}$. Namely, the mean serum $\mathrm{Zn}$ content on the 8th day after inoculation was $0.401 \mathrm{ppm}$ in those bearing YS and $0.542 \mathrm{ppm}$ in those bearing $\mathrm{AH} 66 \mathrm{~F}$.

Influence of anticancer drugs on serum $Z n$ content in the rats bearing tumor. The anticancer drug in a single dose was injected intraperitoneally to the rats bearing YS on the 3rd day after inoculation as described in the section of Materials and Methods. The serum $\mathrm{Zn}$ content was measured every other day after administra- 
Serum $\mathrm{Zn}$ in Tumor-Bearing Rats
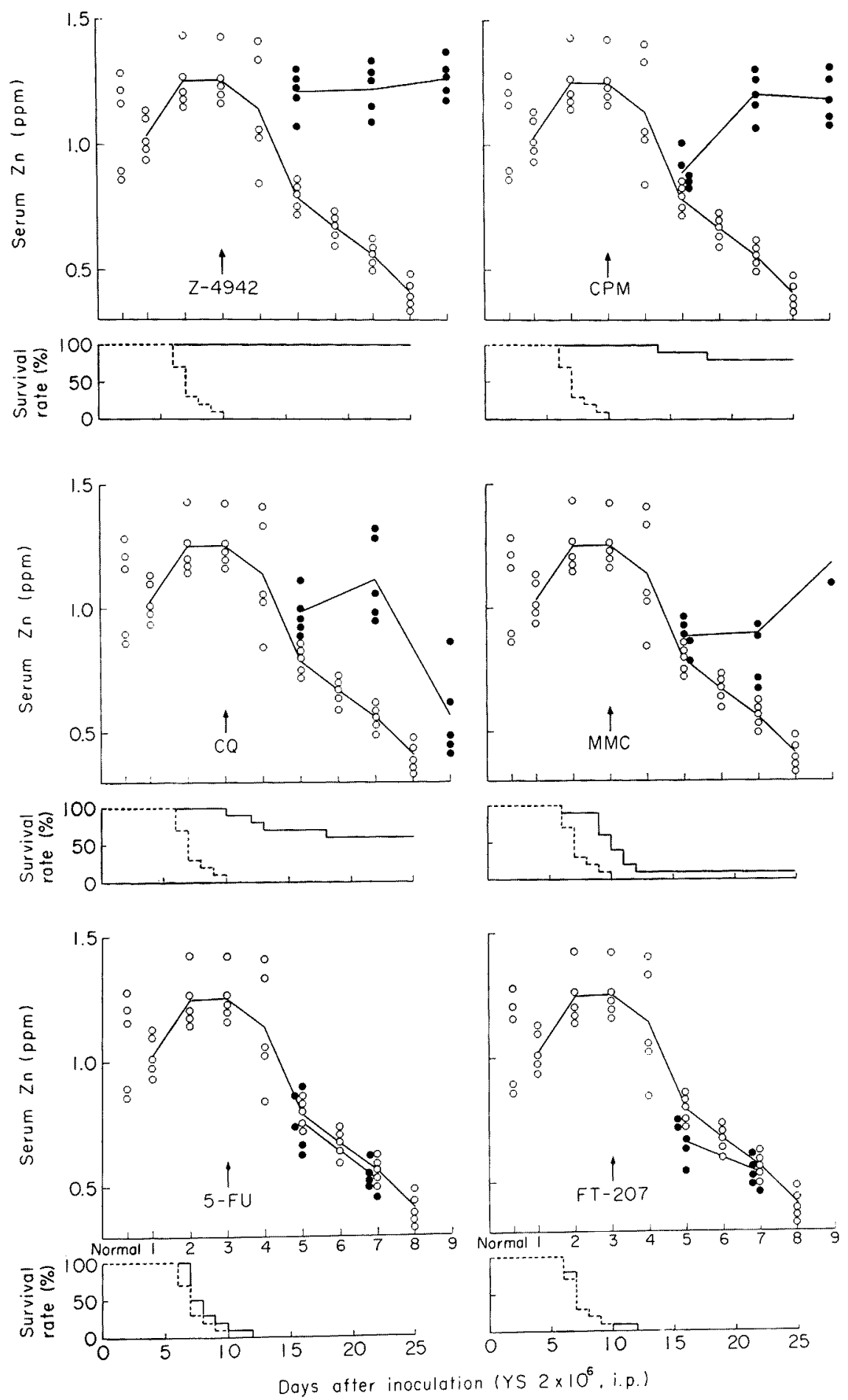

(continued) 

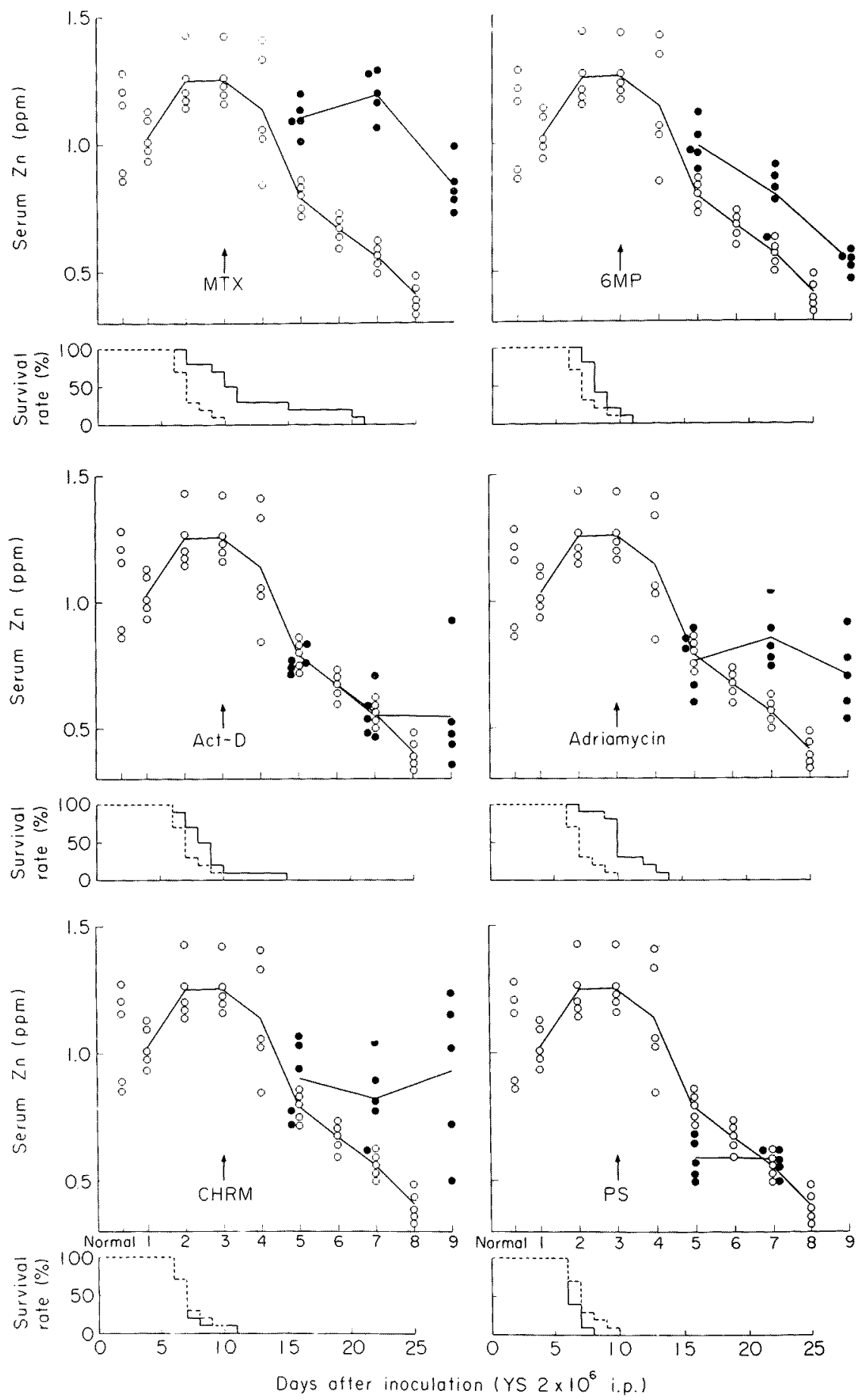

Fig. 3. Fluctuations of serum $\mathrm{Zn}$ content in the rats which had received intraperitoneal inoculum of YS $(0-0)$ and then were treated with anticancer drugs at 3 days after inoculation (-). Survival time is shown on the lower panel of the figure. , tumor control group; $1 \ldots$, group treated with anticancer drugs. 
tion of the drugs (Fig. 3). In the groups which showed a marked response to treatment, such as those treated with CPM or Z-4942, the serum Zn content returned to the normal range on the 2nd day after the initiation of drug administration. Also, in the groups of moderate response to treatment, such as those which had received a single dose of MMC, MTX or ADM, there was a tendency for serum $\mathrm{Zn}$ content to become normal. But in the groups which showed no response to treatment, namely in those treated with 5-FU, FT-207, 6-MP or Act-D, the serum $\mathrm{Zn}$ content was always below normal. In the group given $\mathrm{Ps}$ alone, the survival period of rats was somewhat shorter than that of the untreated controls, and the serum $\mathrm{Zn}$ content was below the normal range as early as the $2 \mathrm{nd}$ day after drug administration. The serum $\mathrm{Zn}$ content of the normal controls was almost unaffected by the drugs.

Influence of tumor inoculation on $\mathrm{Zn}$ content of the organs. The $\mathrm{Zn}$ content of various organs in the normal rats and in the rats bearing YS on the 7th day after subcutaneous inoculation is shown in Fig. 4. The Zn content of the liver in the rats bearing YS was at a significantly high level (135.04 $\pm 2.03 \mu \mathrm{g} / \mathrm{g}$ dry weight) as compared with that in the normal rat $(103.7 \pm 2.38 \mu \mathrm{g} / \mathrm{g}$ dry weight), and that of the kidney was slightly higher than that in the normal rat. An elevation of $\mathrm{Zn}$ content in the liver was found as early as the 3rd day after inoculation, as shown in Fig. 5. In the rats in which a tumor became reduced in size in response to treatment with CPM, there was a slight elevation of $\mathrm{Zn}$ content in the liver on the 2nd day after drug administration as compared with that in the untreated rats. The $\mathrm{Zn}$ content in the treated rats became lower on the 4th day, whereas in the

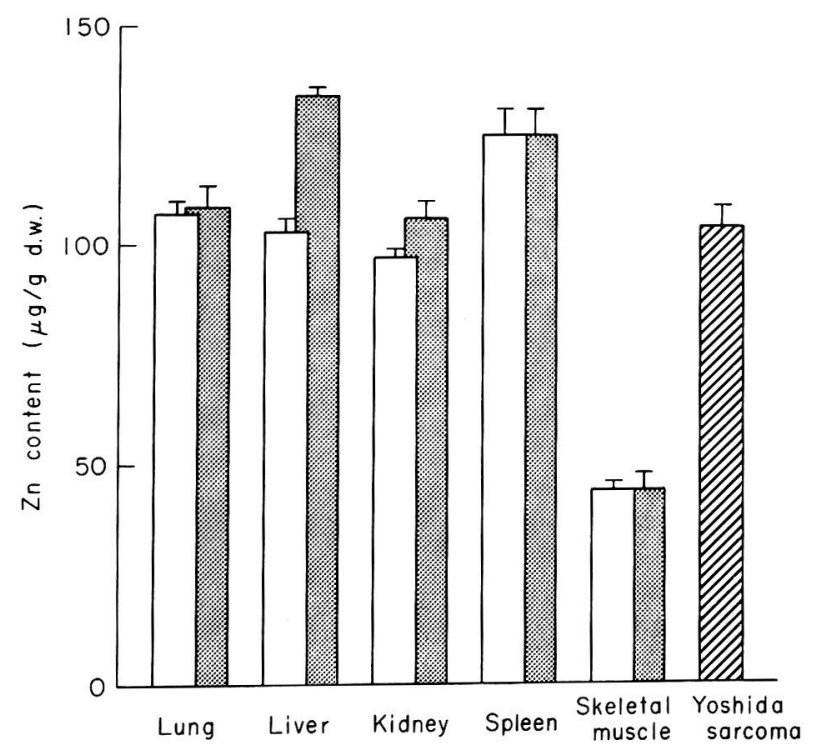

Fig. 4. Zn content of YS tumor volm, and various organs in the normal rats $\square$ and in the rats 7 days after subcutaneous inoculation of YS $\square$. 


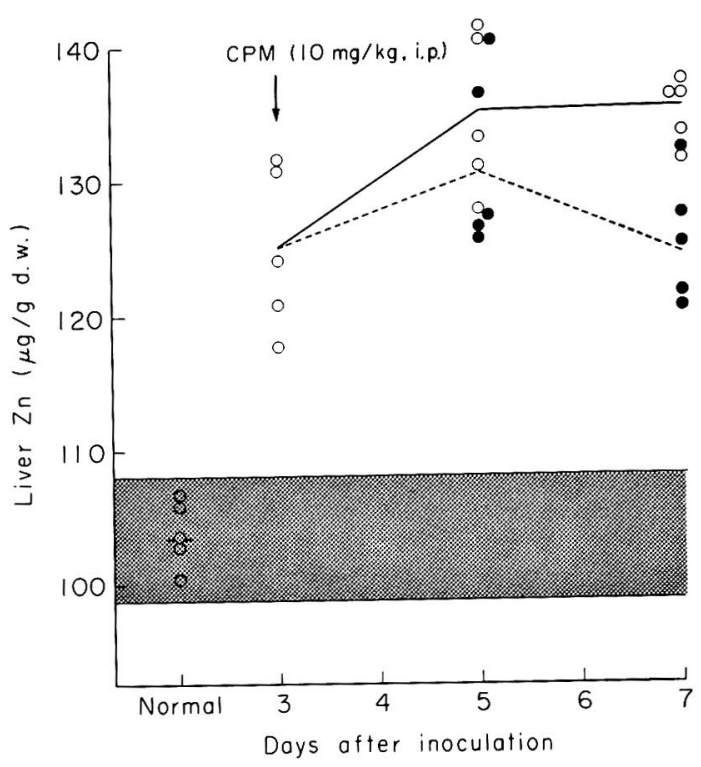

Fig. 5. Fluctuation of liver $\mathrm{Zn}$ content of the rats bearing subcutaneous YS (O-O) and the YS-bearing rats treated with CPM (•--•). Shaded area indicates normal range.

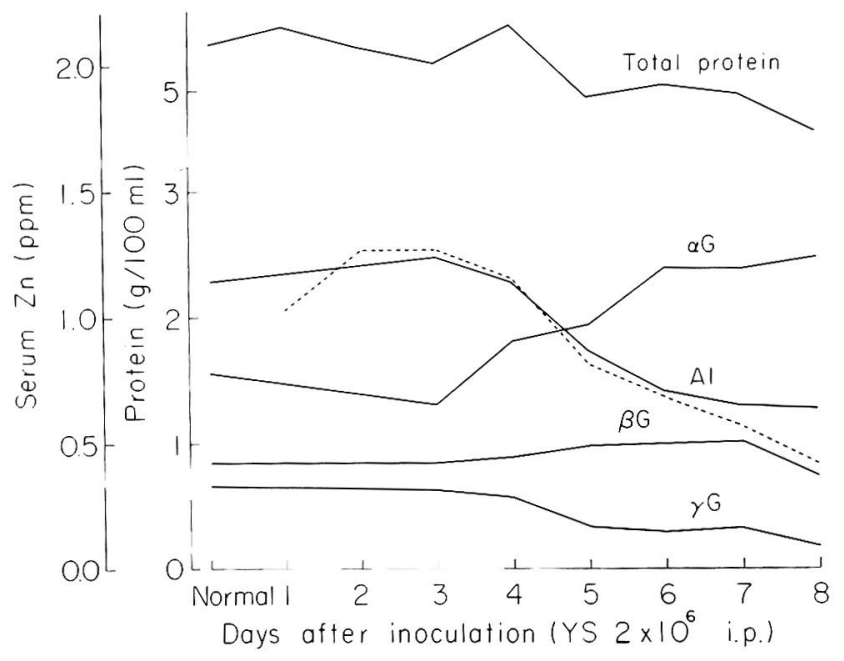

Fig. 6. Fluctuation of total protein, serum protein fractions (analysis by electrophoresis) and of serum $\mathrm{Zn}$ content (-...-) in YS-bearing rats (intraperitoneal).

untreated rats it remained at a relatively constant level.

Influence of tumor inoculation on serum protein. Fig. 6 shows the fluctuation of protein fractions as evidenced by zone electrophoretic analysis. The quantity of protein fractions was expressed in terms of the absolute concentration in serum (total protein $\times$ percentage of each protein fraction: $\mathrm{g} / 100 \mathrm{ml}$ ). 
The fluctuation of albumin paralleled closely with that of the serum $\mathrm{Zn}$ throughout the period of observation. Namely, the albumin increased slightly in the early stage after inoculation. Thereafter, it began to decrease gradually. The decrease was striking in the terminal stage. However, the serum $\mathrm{Zn}$ /albumin ratio and the serum $\mathrm{Zn} /$ total protein ratio, as shown in Fig. 7, continued to fall gradually during the course of experiment. The content of $\alpha$-globulin became markedly elevated by the 4 th day after inoculation, whereas that of $\gamma$-globulin decreased slightly and that of $\beta$-globulin remained at a relatively constant level.

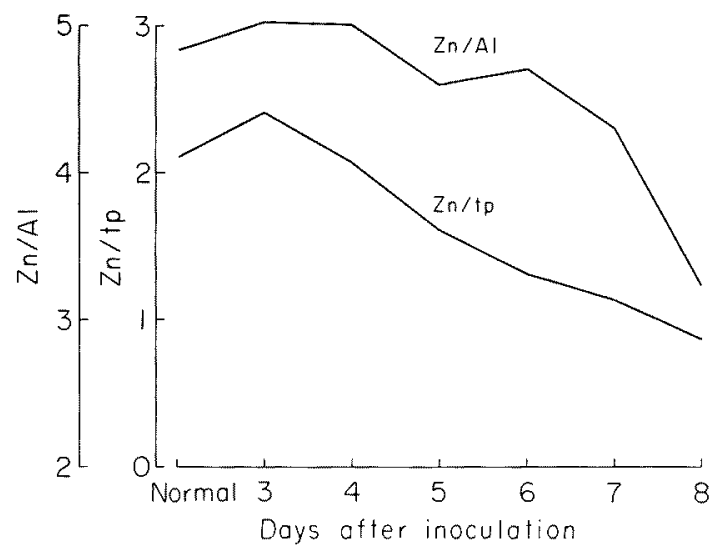

Fig. 7. Serum $\mathrm{Zn} /$ albumin ratio $(\mathrm{Zn} / \mathrm{Al})$ and serum $\mathrm{Zn} /$ total protein ratio $(\mathrm{Zn} / \mathrm{tp})$ in $\mathrm{YS}$ bearing rats (intraperitoneal).

\section{Discussion}

The present investigation on factors which may affect serum $\mathrm{Zn}$ content in normal rats showed no significant differences in serum $\mathrm{Zn}$ content in relation to the length of the period of starvation or body weight.

In the rats bearing tumors, the serum $\mathrm{Zn}$ content increased slightly at an early stage after tumor inoculation, and then it showed a marked decrease throughout the period of the observation.

The above results indicated that the changes in serum $\mathrm{Zn}_{\mathrm{n}}$ content of the rats bearing tumors were closely related to the rate of tumor growth, and that such changes were not the direct consequences of the impaired food intake caused by the tumor.

The underlying mechanism of the reduction of serum $\mathrm{Zn}$ content in the rats bearing tumors remains to be solved yet. The $\mathrm{Zn}$ in blood serum is found in at least two fractions. Usually the firmly bound $\mathrm{Zn}$ amounts to about $34 \%$, and the loosely bound $\mathrm{Zn}$ amounts to $66 \%$ of the total $\mathrm{Zn}$ content (Vallee 1959). The firmly bound $\mathrm{Zn}$ protein ( $\alpha$-globulin) belongs to a metallo-protein and the loosely bound $\mathrm{Zn}$ protein (albumin) to a metal-protein-complex (Dennes et al. 1962; Giroux 1975). The metal-protein-complex appears to be concerned primarily with $\mathrm{Zn}$ transport. Therefore, a reduction of serum albumin may result in a decrease in 
serum $\mathrm{Zn}$ content. The present data showed that both serum $\mathrm{Zn}$ and albumin contents were reduced during the period of tumor growth, but that the degree of the reduction of serum $\mathrm{Zn}$ content was more marked than that of a decrease in serum albumin content. It was thus suggested that a mechanism other than the decrease in serum albumin content should be taken into consideration to account for the reduction of serum $\mathrm{Zn}$ content.

There is the evidence that the decrease in serum $\mathrm{Zn}$ content of the rats bearing tumors may be induced by an accumulation of $\mathrm{Zn}$ in tumor tissues. Many investigators have reported that the tumor tissue contains a large amount of $\mathrm{Zn}$ compared with the normal tissues (Tokuoka 1957; Onoue and Kuroda 1958; Fujii 1959; Tokuoka and Fujiwara 1960; Saegusa 1966; Matsumoto et al. 1969; Matsumoto 1971), and that the $\mathrm{Zn}_{\mathrm{n}}$ bound with plasma protein is readily exchangeable with the pool of body $\mathrm{Zn}$ (Dennes et al. 1962). Our present data from the YS-tissue that had been inoculated subcutaneously into rats confirmed also a high $\mathrm{Zn}$ content in tumor tissues. Presumably the $\mathrm{Zn}$ in tumor is derived from serum $\mathrm{Zn}$. However, the source of $\mathrm{Zn}$ in tumor tissue could not be discussed without the investigation of the routes of absorption and excretion.

It is also conceivable that an accumulation of $\mathrm{Zn}$ in various organs (particularly in the liver) may decrease serum $\mathrm{Zn}$ content in the hosts bearing tumors. As regards this possibility, the present data showed that $\mathrm{Zn}$ content of the liver in the rats bearing tumors was higher than that of the liver in controls. The reason for this is not clear from the results of the present experiment. But it is of interest that the $\mathrm{Zn}$ content in the liver was high around the metastatic lesions (Olson et al. 1954), and that an increase of $\mathrm{Zn}$ content in the liver was found as early as the 3rd day after tumor inoculation and already before the apparent reduction in quantity of $\mathrm{Zn}$ in serum.

Some investigators have shown that anemia is closely related to the reduction of serum Zn content (Prasad et al. 1963; Saegusa 1966; Takano 1969). But no correlation was found between them in our previous publication (Saito et al. 1974).

In the rats bearing YS treated with anticancer drugs, there was a tendency for reduced serum $\mathrm{Zn}$ content to become normal almost in proportion to the degree of prolongation of their survival. It was suggested from the results mentioned above that the fluctuation of serum $\mathrm{Zn}$ content in the hosts bearing tumors during treatment with anticancer drugs can be used as an indicator of the extent of tumor proliferation in the hosts and of the effects of cancer chemotherapy.

\section{References}

1) Dennes, E., Tupper, R. \& Wormall, A. (1962) Studies on zine in blood. Biochem. J., 82, 466-476.

2) Devies, I.J.T., Musa, M. \& Dormandy, T.L. (1968) Measurements of plasma zine. $J$. clin. Path., 21, 359-365.

3) Dewys, W., Pories, W.J., Richter, M.C. \& Strain, W.H. (1970) Inhibition of Walker 256 carcinosarcoma growth by dietary zinc deficiency. Proc. Soc. exp. Biol. Med., 135, $17-22$. 
4) Dewys, W. \& Pories, W.J. (1972) Inhibition of a spectrum of animal tumors by dietary zinc deficiency. J. nat. Cancer Inst., 18, 375-381.

5) Fujii, K. (1959) Studies on zinc in urine of patients with malignant tumor. Osaka Daigaku Igaku Zasshi, 11, 3367-3377. (Japanese)

6) Fujioka, M. \& Lieberman, I. (1964) A $\mathrm{Zn}^{++}$requirement for synthesis of deoxyribonucleic acid by rat liver. J. biol. Chem., 239, 1164-1167.

7) Giroux, E.L. (1975) Determination of zinc destribution between albumin and $\alpha_{2}$ macroglobulin in human serum. Biochem. Med., 12, 258-266.

8) Matsumoto, H. (1971) Studies on zinc determination by atomic absorption spectroscopy and its clinical application. Nichinaikaishi, 60, 13-24. (Japanese)

9) Matsumoto, H., Shiraishi, T. \& Tsunematsu, K. (1969) Zine content of gastric juice in healthy men and patients of gastric disease. Igaku to Seibutsugaku, 78, 39-40. (Japanese)

10) McQuitty, J.T., Dewys, W.D., Monaco, L., Strain, W.H., Rob, C.G., Apgar, J. \& Pories, W.J. (1970) Inhibition of tumor growth by dietary zine deficiency. Cancer Res., 30, 1387-1390.

11) Mills, C.F., Quarterman, J., Chesters, J.K., Williams, R.B. \& Dalgarno, A.C. (1969) Metabolic role of zinc. Amer. J. clin. Nutr., 22, 1240-1249.

12) Morgan, J.M. (1970) Cadmium and zinc abnormalities in bronchogenic carcinoma. Cancer, 25, 1394-1398.

13) Olson, K.B., Heggen, G., Edwards, C.F. \& Gorham, L.W. (1954) Trace element content of cancerous and noncancerous human liver tissue. Science, 119, 772-773.

14) Onoue, K. \& Kuroda, Y. (1958) Component and metabolism of tumor (III). Seikagaku, 30, 119-124. (Japanese)

15) Prasad, A.S., Miale, A., Schulert, A.R., Farid, Z. \& Sandstead, H.H. (1963) Clinical and experimental zinc metabolism in patients with the syndrome of iron deficiency anemia, hepatosplenomegaly, dwarfism and hypogonadism. J. Lab. clin. Med., 61, 537-549.

16) Prasad, A.S., Oberleas, D., Miller, E.R. \& Luecke, R.W. (1971) Biochemical effects of zine deficiency: Changes in activities of zinc-dependent enzymes and ribonucleic acid and deoxyribonucleic acid content of tissues. J. Lab. clin. Med., 77, 144-152.

17) Saegusa, T. (1966) Studies on zinc metabolism in tumor bearing hosts. Osaka Daigaku Igakuzasshi, 18, 11-30. (Japanese)

18) Saito, T., Yokoyama, M., Himori, T., Ujiie, S. \& Sugawara, N. (1974) Pathophysiological studies on serum zine content of tumor-bearing hosts administered with anticancer drugs. Gan to Kagakuryoho, 1, 87-96. (Japanese)

19) Shiraishi, T., Tsunematsu, K. \& Matsumoto, H. (1969) Serum zinc content in tumorbearing rats. Igaku to Seibutsugaku, 78, 31-33. (Japanese)

20) Takano, K. (1969) Studies on serum zinc and copper content in patients with cancer. Gan no Rinshyo, 15, 797-800. (Japanese)

21) Tokuoka, S. (1957) Zine metabolism in cancer patients. Saishin Igaku, 12, 771-781. (Japanese)

22) Tokuoka, S. \& Fujiwara, T. (1960) Distribution of zinc in the various tissues of tumorbearing animals. (I) Studies with ${ }^{65} \mathrm{Zn}$. Gann, 51, Suppl., 20-21.

23) Ujiie, S. (1971) Studies on zinc metabolism of rats bearing tumor. Kokenshi, 23, 4162. (Japanese)

24) Vallee, B. (1959) Biochemistry, physiology and pathology of zinc. Physiol. Rev., 39, 443-490.

25) Wegner, W.S. \& Romano, A.H. (1963) Zine stimulation of RNA and protein synthesis in rhizopus nigricans. Science, 142, 1669-1670. 